\title{
The role of supply chain and product development in sustainable performance, goodwill and firm popularity
}

\author{
Kittisak Jermsittiparsert $\mathrm{a}^{\mathrm{*}}$
}

${ }^{a}$ College of Innovative Business and Accountancy, Dhurakij Pundit University, Thailand

\begin{tabular}{l}
\hline C H R O N I C L E \\
\hline Article history: \\
Received March 10, 2021 \\
Received in revised format May 7, \\
2021 \\
Accepted August 12021 \\
Available online \\
August 32021 \\
\hline Keywords: \\
Rubber Manufacturing Companies \\
Supply Chain \\
Product Development \\
Sustainable Performance \\
Goodwill \\
Firm Popularity
\end{tabular}

\section{A B S T R A C T}

The objective of the current study was to examine the role of supply chain and product development in sustainable performance, goodwill and firm popularity. Furthermore, the mediating role of product development was also examined. Population of the study was rubber manufacturing companies of Indonesia. In this regard, data were collected from the employees of rubber making companies of Indonesia. 500 questionnaires were used for data collection among the rubber making companies. Data was analyzed through statistical software. Results of the analysis revealed that the supply chain has a major contribution to sustainable performance, goodwill and firm popularity. Increase in the supply chain of rubber manufacturing companies, increases the sustainable performance, goodwill and firm popularity. Moreover, product development also has important contributions to the sustainable performance, goodwill and firm popularity. Supply chain has a positive effect on product development and product development has a positive effect on sustainable performance, goodwill and firm popularity.

\section{Introduction}

Rubber industry is an important industry among all countries because the need for rubber products is one of the essential parts of the current era. The requirements of rubber products and increase in the demand of rubber products has increased the importance of rubber making companies. The use of rubber in various industries is most important, as most of the companies cannot survive without rubber or without using the rubber making products. Therefore, the rubber has a central role worldwide (Nabayi, Teh, Husni, \& Sulaiman, 2018; Navaratnarajah \& Indraratna, 2018). Along with the use of rubber in various industries, it also has a significant role among the individual people. Therefore, it has a central role at household level. At industry level, the use of rubber in making different products is most important. Particularly, in the electronics industry, the use of rubber in making electrical products has significant importance. Moreover, the use of rubber is also really important in all other industries. In Indonesia, the role of the rubber industry also has central importance. This industry in Indonesian plays a vital role through different aspects. Firstly, this industry in Indonesia is spread over a wide area having huge investment along with the other companies (Fong, Khin, \& Lim, 2018; Jermsittiparsert, Joemsittiprasert, Wasino, \& Budi, 2019). The huge investment in this industry by Indonesia plays a vital role in revenue generation. This industry provides sufficient revenue to the nation's economy. Therefore, the economic contribution to the local as well as international development has the most important role. At the national level, this industry supports the Indonesian economy along with the other industries. At the local level, this industry creates a number of job opportunities for the Indonesian people. Creating job opportunities also increases the income of people which increases welfare and decreases the level of poverty. Moreover, due to increase in job opportunities, this industry also increases the gross-domestic product (GDP) of the country. Increase in the GDP is one of the positive signs for the economy of the country. Therefore, the rubber industry of Indonesian has a significant role at local and

* Corresponding author

E-mail address: kittisak.jer@dpu.ac.th (K. Jermsittiparsert)

(c) 2021 Growing Science Ltd. All rights reserved.

doi: $10.5267 /$ j.uscm.2021.8.001 
national level. This industry is also contributing to the exports of the country. As the contribution to exports has a vital role in economic development. Generally, Indonesia's natural rubber making is around $80 \%$ for export as well as $20 \%$ for the domestic market. In the year of 2017, Indonesia's top 5 natural rubber importer countries were the United States, India, Japan, Korea and China. Therefore, the United States, India, Japan, Korea and China are the major countries which import rubber from Indonesia and provide significant revenue which is helpful for the Indonesian economy. Some reports show the exports of Indonesia which indicates that Indonesia is exporting $28 \%$ of rubber to the USA, $9 \%$ to Japan, $5 \%$ to Germany, $4 \%$ to China and 4\% to Australia. In 2020, Indonesia will become the third big producer of rubber in the world. Hence, Indonesia has vital importance for the rubber industry in the world which is highlighted from the export volume of rubber. Number of other countries are also producing rubber; however, Indonesia is one of the big producers of rubber. Various countries import the rubber for manufacturing rubber products and then export to the different other countries and these countries import rubber from Indonesia for making different products.

Although the rubber industry of Indonesia is producing significant performance among other countries, this performance can be further increased with the help of various factors. There are three major areas related to the performance. These areas include; sustainable performance, goodwill and firm popularity. Sustainable performance of this industry has vital importance for the companies. Increase in the sustainable performance of each firm in the rubber industry has a positive role to enhance overall performance of this industry. Therefore, sustainable performance of rubber companies has a major role in this industry. As previous studies showed the importance of sustainable performance for various sectors (Ahmed et al., 2020; Shahab et al., 2020). Along with this, the goodwill of this industry related to Indonesia also has an important role. Along with this, the popularity of this industry has importance because most of the countries import rubber from Indonesia. Increase in the popularity of Indonesian industry will increase the exports of this industry and ultimately increase the performance. Therefore, the government of Indonesia should focus on sustainable performance, goodwill and firm popularity. However, these three areas; sustainable performance, goodwill and firm popularity. Supply chain is a vital role among the companies to enhance the performance (Ul-Hameed, Mohammad, Shahar, Aljumah, \& Azizan, 2019). Hence, better supply chain practices should be applied to enhance the performance of the rubber industry. Furthermore, this study also examined the effect of product development on sustainable performance, goodwill and firm popularity. As the product development has vital importance among the companies (Bouncken, Fredrich, Ritala, \& Kraus, 2018; Haryanto, Dewi, \& Choerudin, 2020). It also has vital importance among the rubber manufacturing companies of Indonesia. To increase the sustainable performance, goodwill and firm popularity of rubber companies, rubber product development has vital importance which has a vital contribution to rubber companies. According to this study, supply chain effects positively on product development and product development has positive influence to increase sustainable performance, goodwill and firm popularity. Hence, this study examined the relationship between supply chain, product development, sustainable performance, goodwill and firm popularity. This relationship is quite unique in the area of rubber manufacturing companies. Uniqueness of this relationship in this industry has a vital role to contribute to the literature. As the contribution of this relationship in theory is vital, therefore, the practical contribution of this relationship is also very common in rubber making companies. Hence, the objective of the current study is to examine the role of supply chain and product development in sustainable performance, goodwill and firm popularity.

\section{Literature Review}

Rubber manufacturing is the most important part of today's market as the use of rubber is quite important among all the industries for making different products. In this regard the importance of rubber manufacturing has significant value. Particularly, for the rubber manufacturing, trees have the most important role (Boonyaratchinda \& Kongkarat, 2020; Saffian, Harun, Tahir, \& Khalina, 2011). In the whole world, counties are getting rubber from the trees. The portion of natural rubber from the trees has a major part in the overall rubber production in the world. Now most of the countries are trying to increase the number of rubber trees to extract the highest amount of rubber to fulfill the need and for the export purpose. Indonesia is also one of the countries which is focusing on growing rubber trees. Indonesia has significant potential for rubber trees and various rubber manufacturing companies.

Rubber is harvested from rubber trees, which are a family of trees that are related to the family Euphorbiace; Hevea brasilienisis or Sharinga trees which are the most common. Natural rubber is mined by a technique called tapping, by making cuts into the bark as well as collecting the fluid into vessels attached to the rubber trees. Therefore, trees are the major sources of rubber manufacturing. As the current study is dealing with the rubber manufacturing in Indonesia, there are a number of rubber trees in Indonesia. Indonesia is extracting rubber from a number of trees. Major portion of Indonesian rubber comes from the trees. Therefore, trees in Indonesia are a major producer of rubber. However, various factors are affecting rubber making companies in Indonesia. First of all, the supply chain is the major part of rubber manufacturing firms. Supply chain has a central role in sustainable performance, goodwill and firm popularity. Furthermore, product development also has a significant role in sustainable performance, goodwill and firm popularity. The relationship between supply chain, product development, sustainable performance, goodwill and firm popularity is shown in Fig. 1. 


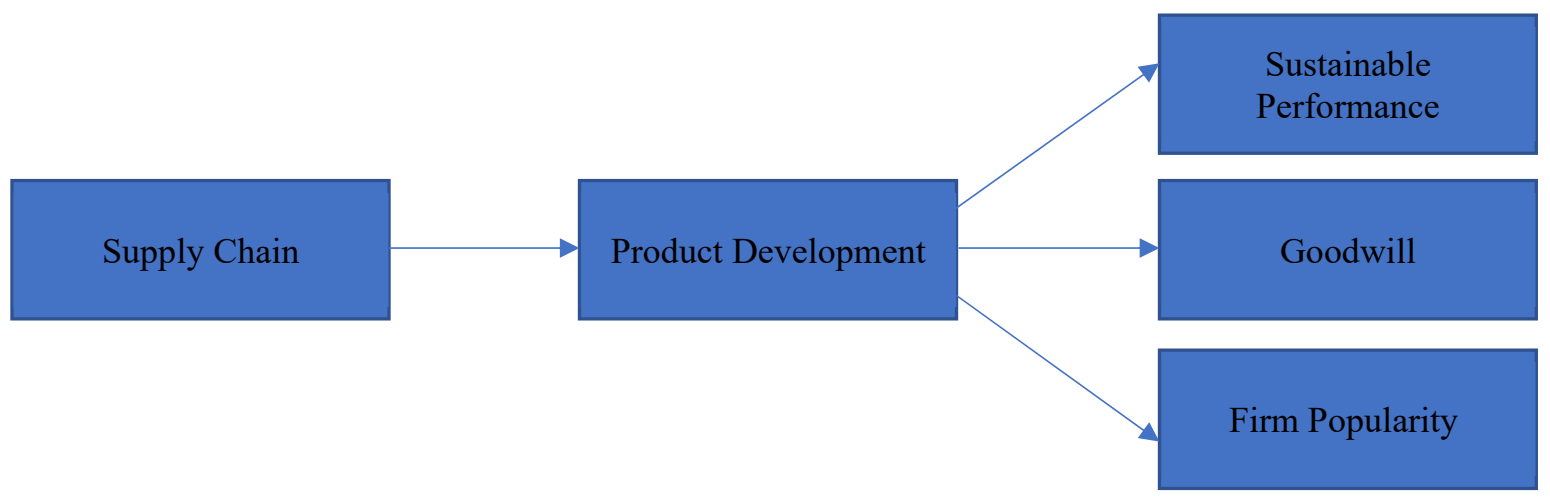

Fig. 1. The relationship between supply chain, product development, sustainable performance, goodwill and firm popularity

\subsection{Hypotheses Development}

Supply chain is the most vital element of each industry. In each firm, the supply chain is planning a vital contribution to the performance through a number of operations starting from raw material extraction to the delivery of goods to the customers. Therefore, the importance of the supply chain in rubber making companies cannot be neglected. It always requires the highest priority to get a better level of performance. In rubber making companies, raw material for rubber is required. Raw material of rubber is required from the rubber trees. Therefore, to make the rubber products, the raw material related to the rubber is required which can be extracted from the trees. Number of studies highlighted the rubber manufacturing (Abbas, Hussein, \& Mohammad, 2018; Dasanayaka \& Sardana, 2017); however, these previous investigations could not cover the role of the supply chain which is filled by the current study. Therefore, product development in rubber making companies is important which is based on the supply chain. The raw material comes from rubber making companies that can enhance product development. Therefore, product development in these companies is based on the supply chain. Hence, this led to the following hypothesis;

\section{Hypothesis 1. Supply chain has a positive influence in product development.}

Product development characteristically denotes all of the stages included in carrying a product from one idea, with the help of market release as well as beyond. In other words, it can be described as, product development joins a product's whole journey, involving recognizing a market requirement. Conceptualizing as well as designing the product is most important. It is the vital part of any manufacturing company. Because products manufactured among the companies have major importance for the success of the company. Better product development is important for the achievement. Product development has a positive role in sustainable performance. Better development of products has a positive role to enhance the sustainable performance in Indonesian manufacturing companies. Similar to this, various studies showing the positive relationship between product development and sustainable performance (J. Abbas et al., 2019; Schöggl, Baumgartner, \& Hofer, 2017). Therefore, product development has a positive influence on sustainable performance.

Hypothesis 2. Product development has a positive influence on sustainable performance.

Moreover, product development also has a role in goodwill of the company. Goodwill is the most important factor of any organization. The companies having a significant level of goodwill in the market shows a positive role in the industry as well in the performance. Generally, product development has a relationship with goodwill. Better product development promotes the goodwill in the market by the specific company. Hence, increase in product development has the ability to increase goodwill. As the literature shows the relationship between product development and goodwill (Cho, Bonn, \& Terrell, 2019; Hofman, Schleimer, \& Faems, 2018). It is important because goodwill is the most important part of every company which can lead to better performance. Therefore, this discussion highlighted that;

Hypothesis 3. Product development has a positive influence on goodwill.

Furthermore, this study also scrutinized the relationship between product development and firm popularity. The state or condition of being liked, admired, or supported by many people. It is required to increase the sales and increase the customer attraction. Low popularity has a negative effect on the sales of the company and revenue generation. The companies having better popularity generally show a positive role in the performance. As the popular business always required high profile customers. Previous section shows that product development cannot be challenged positively, however, low availability of the companies has a negative effect on performance. Previous studies also showed the relationship between product development and performance (Cheng \& Krumwiede, 2018; Schöggl et al., 2017). Therefore, along with the other variables, product development also has a positive effect on firm popularity. 
Hypothesis 4. Product development has a positive influence on firm popularity.

In the above section, it is discussed that supply chain has a major role in product development. Product development has an effect on sustainable performance, goodwill and firm popularity. However, this section shows the indirect effect of product development. The mediation effect of product development was examined between supply chain and sustainable performance. The mediation outcome of product development was examined between supply chain and goodwill. Finally, the mediation effect of product development was examined between supply chain and firm popularity. The approach of Baron and Kenny (1986) was followed for mediation results. The mediation effect of product development is examined as shown in below hypotheses.

Hypothesis 5. Product development mediates the relationship between supply chain and sustainable performance.

Hypothesis 6. Product development mediates the relationship between supply chain and good will.

Hypothesis 7. Product development mediates the relationship between supply chain and firm popularity.

\section{Research Methodology}

The relationship between supply chain, product development, sustainable performance, goodwill and firm popularity was examined after designing a research questionnaire. Survey questionnaire was designed to measure all these variables (Bowling, Bond, Jenkinson, \& Lamping, 1999). With the help of a questionnaire, five variables, namely; supply chain, product development, sustainable performance, goodwill and firm popularity were measured. Questionnaires were designed with the help of previous studies. Questionnaire was prepared into sections as per the requirement. This study also considered the general information about the respondents. Therefore, one of the sections was prepared to collect the general information about the respondents related to their marital status, age, income and profession. However, the other section was developed to examine the relationship between variables and to collect data with the help of scale items. Hence, the second section was grounded on the scale items related to the key study variables; supply chain, product development, sustainable performance, goodwill and firm popularity. Finally, after preparation of questionnaires, data were collected from the rubber manufacturing companies of Indonesia. 500 questionnaires were circulated among the employees of rubber manufacturing firms. Therefore, the population of the study is rubber manufacturing firms and employees of these companies are the respondents. A survey was carried out with the help of simple random sampling (Siuly, Li, \& Wen, 2011). From the total 500 questionnaires, 305 were returned and used in data analysis. After the collection of data, it was examined through data screening to check the missing value along with the outlier (Aydin \& ŞENOĞLU, 2018). The missing value in the data or outlier can change the results. Thus, all the missing values and outlier in the data were removed. Now the data is free from any case of missing value and outlier as shown in Table 1.

Table 1

Data Statistics

\begin{tabular}{|c|c|c|c|c|c|c|c|c|c|}
\hline & No. & Missing & Mean & Median & Min & Max & SD & Kurtosis & Skewness \\
\hline $\mathrm{SC} 1$ & 1 & 0 & 4.018 & 4 & 1 & 5 & 0.994 & -1.24 & -1.62 \\
\hline $\mathrm{SC} 2$ & 2 & 0 & 2.249 & 4 & 1 & 5 & 1.14 & -1.571 & -1.406 \\
\hline $\mathrm{SC} 3$ & 3 & 0 & 3.5 & 4 & 1 & 5 & 0.982 & -0.394 & -0.655 \\
\hline $\mathrm{SC} 4$ & 4 & 0 & 3.505 & 4 & 1 & 5 & 1.227 & -0.522 & -0.605 \\
\hline SC5 & 5 & 0 & 3.407 & 4 & 1 & 5 & 1.219 & -0.774 & -1.476 \\
\hline SC6 & 6 & 0 & 2.95 & 4 & 1 & 5 & 1.25 & -1.656 & -1.591 \\
\hline SC7 & 7 & 0 & 3.618 & 4 & 1 & 5 & 0.992 & -0.46 & -0.581 \\
\hline SC8 & 8 & 0 & 3.627 & 4 & 1 & 5 & 1.124 & -0.217 & -0.666 \\
\hline SC9 & 9 & 0 & 3.73 & 4 & 1 & 5 & 1.272 & -0.467 & -0.791 \\
\hline $\mathrm{SC} 10$ & 10 & 0 & 2.932 & 4 & 1 & 5 & 1.247 & -1.61 & -1.648 \\
\hline PRD1 & 11 & 0 & 3.598 & 4 & 1 & 6 & 1.312 & -0.847 & -0.511 \\
\hline PRD2 & 12 & 0 & 3.574 & 4 & 1 & 5 & 0.99 & -0.443 & -0.63 \\
\hline PRD3 & 13 & 0 & 3.618 & 4 & 1 & 5 & 1.172 & -0.595 & -0.562 \\
\hline PRD4 & 14 & 0 & 3.574 & 4 & 1 & 6 & 1.192 & -1.465 & -1.491 \\
\hline PRD5 & 15 & 0 & 3.725 & 4 & 1 & 5 & 1.016 & -0.623 & -0.359 \\
\hline SP1 & 16 & 0 & 2.745 & 4 & 1 & 5 & 0.931 & -0.685 & -0.365 \\
\hline SP2 & 17 & 0 & 3.51 & 4 & 1 & 5 & 1.161 & -1.311 & -0.649 \\
\hline SP3 & 18 & 0 & 3.564 & 4 & 1 & 5 & 1.249 & -0.581 & -1.618 \\
\hline SP4 & 19 & 0 & 3.446 & 4 & 1 & 5 & 1.245 & -0.821 & -0.467 \\
\hline GW1 & 20 & 0 & 2.967 & 4 & 1 & 5 & 1.187 & -0.445 & -0.641 \\
\hline GW2 & 21 & 0 & 3.657 & 4 & 1 & 5 & 1.146 & -1.315 & -0.636 \\
\hline GW3 & 22 & 0 & 3.75 & 4 & 1 & 5 & 1.968 & -0.387 & -1.841 \\
\hline GW4 & 23 & 0 & 3.652 & 4 & 1 & 5 & 1.269 & -0.622 & -0.672 \\
\hline FP1 & 24 & 0 & 3.554 & 4 & 1 & 6 & 1.273 & -1.727 & -0.524 \\
\hline FP2 & 25 & 0 & 3.667 & 4 & 1 & 5 & 1.199 & -0.41 & -0.708 \\
\hline FP3 & 26 & 0 & 3.946 & 4 & 1 & 5 & 0.94 & 1.249 & -1.032 \\
\hline FP4 & 27 & 0 & 3.946 & 4 & 1 & 5 & 0.991 & 0.527 & -0.926 \\
\hline
\end{tabular}

Note: $\mathrm{SC}=$ Supply Chain: PRD = Product Development; SP = Sustainable Performance; GW = Goodwill; FP = Firm Popularity 
Moreover, this study used the most popular data analysis software, namely; Partial Least Square (PLS) to analyze the data (F. Hair et al. , 2014; J. F. Hair, 2010; J. F. Hair, Ringle, \& Sarstedt, 2013; J. F. Hair, Sarstedt, Pieper, \& Ringle, 2012; Hameed, Basheer, Iqbal, Anwar, \& Ahmad, 2018) which was collected from the employees of Indonesian rubber making companies. The very first part of PLS is given in Fig. 2.

\section{Research Findings}

It is given in Fig. 2 that supply chain is measured with the help of 10 scale items and product development is measured with the help of five scale items. The factor loadings of these scale items are highlighted in Table 2. Along with this, the scale items for sustainable performance is four and scale items for goodwill is also four. Finally, scale items for firm popularity are only two. Two items of firm popularity were deleted due to factor loadings below 0.5 . The minimum level for factor loadings is 0.5 in this study. According to J. Hair et al. (2017), it must be above 0.7 , however few studies suggested to retain above 0.5 which is followed in the current study.

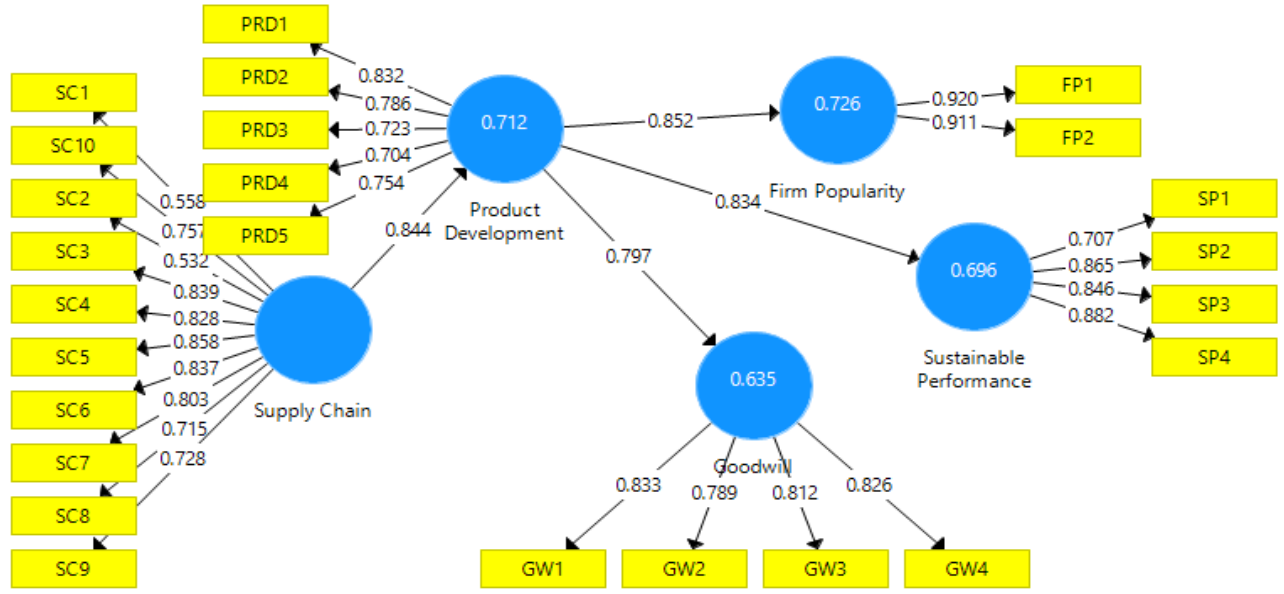

Fig. 2. Outer Model

Table 2

Factor Loadings

\begin{tabular}{|c|c|c|c|c|c|}
\hline & Firm Popularity & Goodwill & Product Development & Supply Chain & Sustainable Performance \\
\hline FP1 & 0.92 & & & & \\
\hline FP2 & 0.911 & & & & \\
\hline GW1 & & 0.833 & & & \\
\hline GW2 & & 0.789 & & & \\
\hline GW3 & & 0.812 & & & \\
\hline GW4 & & 0.826 & & & \\
\hline PRD1 & & & 0.832 & & \\
\hline PRD2 & & & 0.786 & & \\
\hline PRD3 & & & 0.723 & & \\
\hline PRD4 & & & 0.704 & & \\
\hline PRD5 & & & 0.754 & & \\
\hline $\mathrm{SC} 1$ & & & & 0.558 & \\
\hline $\mathrm{SC} 10$ & & & & 0.757 & \\
\hline $\mathrm{SC} 2$ & & & & 0.532 & \\
\hline $\mathrm{SC} 3$ & & & & 0.839 & \\
\hline $\mathrm{SC} 4$ & & & & 0.828 & \\
\hline SC5 & & & & 0.858 & \\
\hline SC6 & & & & 0.837 & \\
\hline $\mathrm{SC} 7$ & & & & 0.803 & \\
\hline SC8 & & & & 0.715 & \\
\hline SC9 & & & & 0.728 & \\
\hline SP1 & & & & & 0.707 \\
\hline SP2 & & & & & 0.865 \\
\hline SP3 & & & & & 0.846 \\
\hline SP4 & & & & & 0.882 \\
\hline
\end{tabular}

Along with factor loadings, this study also examined composite reliability (CR) and convergent validity. Discriminant validity was examined through cross-loadings as given in Table 4 (Fornell \& Larcker, 1981). Average variance extracted (AVE) was examined for convergent validity. Table 3 shows that CR for supply chain, product development, sustainable performance, 
goodwill and firm popularity is above 0.7. Moreover, AVE for supply chain, product development, sustainable performance, goodwill and firm popularity is above 0.5 which confirmed the convergent validity.

Table 3

Outer Model Results

\begin{tabular}{lllll}
\hline & Alpha & rho_A & CR & AVE \\
\hline Firm Popularity & 0.807 & 0.809 & 0.912 & 0.838 \\
Goodwill & 0.831 & 0.833 & 0.664 & 0.873 \\
Product Development & 0.824 & 0.849 & 0.58 \\
Supply Chain & 0.912 & 0.917 & 0.928 & 0.568 \\
Sustainable Performance & 0.844 & 0.843 & 0.896 \\
\hline
\end{tabular}

Note: $\mathrm{SC}=$ Supply Chain: PRD = Product Development; SP = Sustainable Performance; GW = Goodwill; FP = Firm Popularity

Table 4

Cross-Loadings

\begin{tabular}{|c|c|c|c|c|c|}
\hline & Firm Popularity & Goodwill & Product Development & Supply Chain & Sustainable Performance \\
\hline FP1 & 0.92 & 0.794 & 0.799 & 0.765 & 0.716 \\
\hline FP2 & 0.911 & 0.758 & 0.76 & 0.777 & 0.71 \\
\hline GW1 & 0.701 & 0.833 & 0.689 & 0.803 & 0.763 \\
\hline GW2 & 0.692 & 0.789 & 0.634 & 0.673 & 0.622 \\
\hline GW3 & 0.702 & 0.812 & 0.644 & 0.737 & 0.666 \\
\hline GW4 & 0.669 & 0.826 & 0.628 & 0.757 & 0.687 \\
\hline PRD1 & 0.789 & 0.777 & 0.832 & 0.771 & 0.718 \\
\hline PRD2 & 0.757 & 0.739 & 0.786 & 0.768 & 0.682 \\
\hline PRD3 & 0.418 & 0.443 & 0.823 & 0.53 & 0.56 \\
\hline PRD4 & 0.418 & 0.437 & 0.704 & 0.478 & 0.496 \\
\hline PRD5 & 0.45 & 0.503 & 0.754 & 0.561 & 0.673 \\
\hline $\mathrm{SC} 1$ & 0.392 & 0.374 & 0.54 & 0.558 & 0.474 \\
\hline SC10 & 0.694 & 0.617 & 0.645 & 0.757 & 0.673 \\
\hline $\mathrm{SC} 2$ & 0.3 & 0.337 & 0.533 & 0.582 & 0.453 \\
\hline $\mathrm{SC} 3$ & 0.738 & 0.715 & 0.665 & 0.839 & 0.78 \\
\hline $\mathrm{SC} 4$ & 0.686 & 0.753 & 0.657 & 0.828 & 0.805 \\
\hline SC5 & 0.698 & 0.737 & 0.675 & 0.858 & 0.839 \\
\hline SC6 & 0.695 & 0.72 & 0.657 & 0.837 & 0.754 \\
\hline SC7 & 0.668 & 0.779 & 0.673 & 0.803 & 0.756 \\
\hline SC8 & 0.674 & 0.742 & 0.64 & 0.815 & 0.615 \\
\hline SC9 & 0.7 & 0.787 & 0.641 & 0.828 & 0.656 \\
\hline SP1 & 0.411 & 0.517 & 0.708 & 0.552 & 0.727 \\
\hline SP2 & 0.763 & 0.764 & 0.701 & 0.821 & 0.865 \\
\hline SP3 & 0.681 & 0.76 & 0.643 & 0.805 & 0.846 \\
\hline SP4 & 0.718 & 0.741 & 0.694 & 0.843 & 0.882 \\
\hline
\end{tabular}

Note: $\mathrm{SC}=$ Supply Chain: $\mathrm{PRD}=$ Product Development; SP = Sustainable Performance; GW = Goodwill; FP = Firm Popularity

Given in the Fig. 3 is PLS structural model for hypotheses testing recommended by many studies in the literature (Henseler \& Chin, 2010; Henseler et al., 2014; Henseler, Ringle, \& Sinkovics, 2009; Iqbal \& Kousar, 2018). The direct effect of the supply chain is examined on product development. The direct effect of product development was examined on sustainable performance. Moreover, the direct effect of product development was examined on goodwill. Finally, the direct effect of product development was examined on firm popularity. Results in Table 4 shows that the supply chain has a positive effect on product development. Better supply chain promotes product development. Findings of the study also shows that product development has a positive effect on performance sustainability. Moreover, product development has a positive effect on goodwill. The positive effect of product development was found on firm popularity.

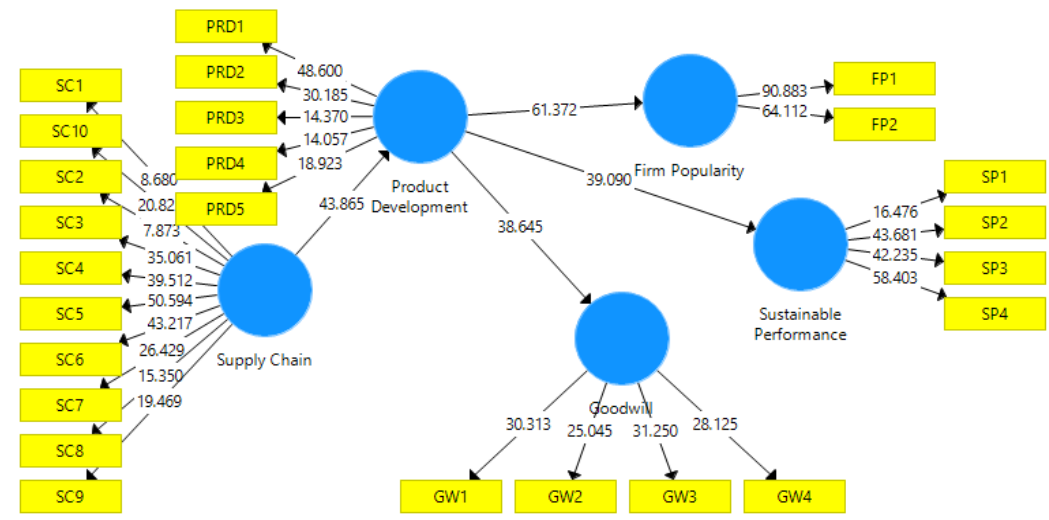

Fig. 3. Structural Model 
Table 5

Direct Effect Results

\begin{tabular}{|c|c|c|c|c|c|}
\hline & (O) & (M) & SD & T Statistics & P Values \\
\hline Product Development -> Firm Popularity & 0.852 & 0.854 & 0.014 & 61.372 & 0 \\
\hline Product Development -> Goodwill & 0.797 & 0.798 & 0.021 & 38.645 & 0 \\
\hline Product Development $->$ Sustainable Performance & 0.834 & 0.834 & 0.021 & 39.09 & 0 \\
\hline Supply Chain -> Product Development & 0.844 & 0.844 & 0.019 & 43.865 & 0 \\
\hline
\end{tabular}

Note: $\mathrm{SC}=$ Supply Chain: PRD = Product Development; SP = Sustainable Performance; GW = Goodwill; FP = Firm Popularity

The instructions of Preacher and Hayes (2008) were followed in the current study to examine the mediation effect of product development. The mediation effect of product development was examined between supply chain and sustainable performance. The mediation effect of product development was examined between supply chain and goodwill. Finally, the mediation effect of product development was examined between supply chain and firm popularity. The mediation effect of product development between supply chain and sustainable performance found t-value 22.052 which is significant and shows that product development reflects the positive effect of supply chain on performance sustainability. The mediation effect of product development between supply chain and goodwill is significant with t-value 22.214 . Finally, the mediation effect of product development between supply chain and firm popularity has t-value 29.708 which is significant. Thus, product development as mediating variables reflect the positive effect of supply chain on sustainable performance, goodwill and firm popularity. All these mediation effects are given in Fig. 4, Fig. 5 and Fig. 6. The r-square value for sustainable performance, goodwill and firm popularity is strong as shown in Figure 3 (Chin, 1998). It shows that supply chain and product development have a strong influence on sustainable performance, goodwill and firm popularity.

Table 6

Indirect Effect Results

\begin{tabular}{|c|c|c|c|c|c|}
\hline & (O) & $(\mathbf{M})$ & SD & T Statistics & P Values \\
\hline Supply Chain $\rightarrow$ Product Development $\rightarrow$ Firm Popularity & 0.719 & 0.721 & 0.024 & 29.708 & 0 \\
\hline Supply Chain $\rightarrow$ Product Development $\rightarrow$ Goodwill & 0.673 & 0.674 & 0.03 & 22.214 & 0 \\
\hline Supply Chain $\rightarrow$ Product Development $\rightarrow$ Sustainable Performance & 0.704 & 0.704 & 0.032 & 22.052 & 0 \\
\hline
\end{tabular}

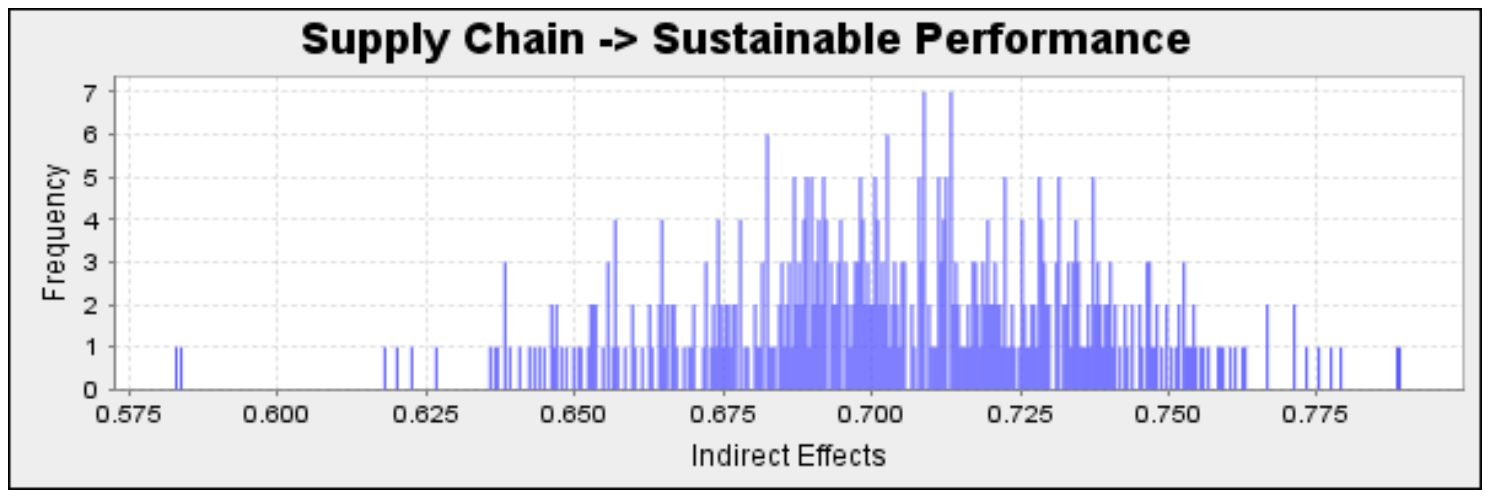

Fig. 4. Indirect Effect: Supply Chain $\rightarrow$ Product Development $\rightarrow$ Sustainable Performance

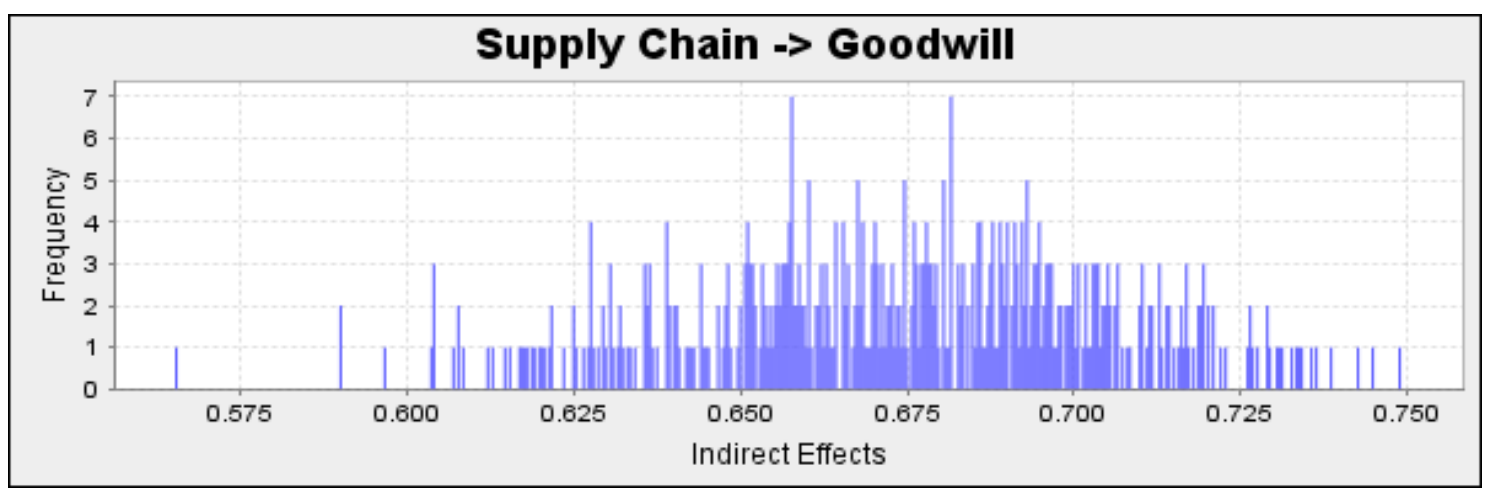

Fig. 5. Indirect Effect: Supply Chain $\rightarrow$ Product Development $\rightarrow$ Goodwill 


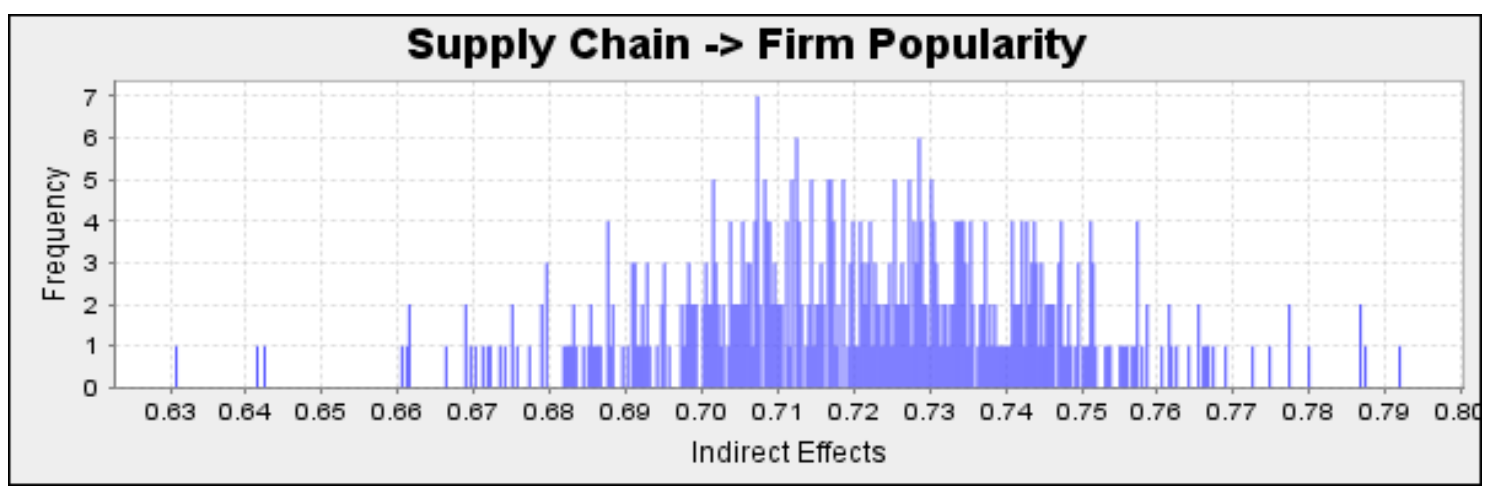

Fig. 6. Indirect Effect: Supply Chain $\rightarrow$ Product Development $\rightarrow$ Firm Popularity

\section{Conclusion}

The current study has observed the relationship between supply chain, product development, sustainable performance, goodwill and firm popularity. The objective of the current study was to examine the role of supply chain and product development in sustainable performance, goodwill and firm popularity. Population of the study is rubber manufacturing companies of Indonesia and data were collected from employees through a survey questionnaire. This unique relationship provided valuable results for the rubber manufacturing companies and theory. According to the findings, the rubber manufacturing firms can be promoted with the help of the supply chain. Outcomes of the analysis discovered that the supply chain has a major contribution to sustainable performance, goodwill and firm popularity. Improvement in supply chain has a helpful role in business sustainability of rubber making companies. Increase in supply chain also has a positive role in goodwill. This supply chain was quite helpful to enhance the firm's popularity. Therefore, increase in the supply chain of rubber manufacturing companies, increase the sustainable performance, goodwill and firm popularity. Thus, supply chain has a significant and positive effect on sustainable performance, goodwill and firm popularity. In this direction, product development also has a major contribution to reflect the positive effect of the supply chain on sustainable performance, goodwill and firm popularity. Besides, product development also has important contributions to the sustainable performance, goodwill and firm popularity. Product development has a positive effect on sustainable performance. It also has a positive effect on goodwill and firm popularity. Supply chain has a positive effect on product development and product development has a positive effect on sustainable performance, goodwill and firm popularity.

\section{Implications of the study}

The valuable relationship was examined between supply chain, product development, sustainable performance, goodwill and firm popularity. This relationship has vital importance for the literature because none of the previous studies examined this relationship between variables. This is the first investigation which examined the effect of supply chain on sustainable performance, goodwill and firm popularity in rubber making companies of Indonesia. Further to this, the current study examined three mediation effects of product development which are unique contributions. The mediation effect of product development was examined between supply chain and sustainable performance. The mediation effect of product development was examined between supply chain and goodwill. Finally, the mediation effect of product development was examined between supply chain and firm popularity. Finally, this study is valuable for the rubber making companies to enhance the performance.

\section{References}

Abbas, A. A., Hussein, M. A., \& Mohammad, M. M. (2018). Design Parameters Estimation and Design Sensitivity Analysis in Manufacturing Process of Rubber Pad by Using Finite Element Technique. Int. J. Mech. Mechatronics Eng, 18(03), 7585.

Abbas, J., Mahmood, S., Ali, H., Ali Raza, M., Ali, G., Aman, J., . . Nurunnabi, M. (2019). The Effects of Corporate Social Responsibility Practices and Environmental Factors through a Moderating Role of Social Media Marketing on Sustainable Performance of Business Firms. Sustainability, 11(12), 3434.

Ahmed, W., Ashraf, M. S., Khan, S. A., Kusi-Sarpong, S., Arhin, F. K., Kusi-Sarpong, H., \& Najmi, A. (2020). Analyzing the impact of environmental collaboration among supply chain stakeholders on a firm's sustainable performance. Operations Management Research, 1-18.

Aydin, D., \& ŞENOĞLU, B. (2018). Estimating the Missing Value in One-Way Anova Under Long-Tailed Symmetric Error Distributions. Sigma: Journal of Engineering \& Natural Sciences/Mühendislik ve Fen Bilimleri Dergisi, 36(2).

Baron, R. M., \& Kenny, D. A. (1986). The moderator-mediator variable distinction in social psychological research: Conceptual, strategic, and statistical considerations. Journal of personality and social psychology, 51(6), $1173-1182$. 
Boonyaratchinda, M., \& Kongkarat, S. (2020). Fundamental Investigation of Ferrosilicon Production Using Rice Husk and Rubber Tree Bark at $1550^{\circ}$ C: Implication for Utilization of Agricultural Waste in Steelmaking Industry. Paper presented at the Materials Science Forum.

Bouncken, R. B., Fredrich, V., Ritala, P., \& Kraus, S. (2018). Coopetition in new product development alliances: advantages and tensions for incremental and radical innovation. British Journal of management, 29(3), 391-410.

Bowling, A., Bond, M., Jenkinson, C., \& Lamping, D. (1999). Short Form 36 (SF-36) Health Survey questionnaire: which normative data should be used? Comparisons between the norms provided by the Omnibus Survey in Britain, the Health Survey for England and the Oxford Healthy Life Survey. Journal of Public Health, 21(3), 255-270.

Cheng, C. C., \& Krumwiede, D. (2018). Enhancing the performance of supplier involvement in new product development: the enabling roles of social media and firm capabilities. Supply Chain Management: An International Journal.

Chin, W. W. (1998). The partial least squares approach to structural equation modeling. Modern methods for business research, 295(2), 295-336.

Cho, M., Bonn, M. A., \& Terrell, B. B. (2019). Interaction effects between contract specificity, competence trust and goodwill trust upon supplier opportunism and relational stability. International Journal of Contemporary Hospitality Management.

Dasanayaka, S., \& Sardana, G. (2017). Identification of factors affecting productivity of small and medium scale enterprises in Sri Lanka: a case study on rubber manufacturing sector. World Review of Entrepreneurship, Management and Sustainable Development, 13(4), 389-417.

F. Hair Jr, J., Sarstedt, M., Hopkins, L., \& G. Kuppelwieser, V. (2014). Partial least squares structural equation modeling (PLS-SEM) An emerging tool in business research. European Business Review, 26(2), 106-121.

Fong, Y. C., Khin, A. A., \& Lim, C. S. (2018). Conceptual Review and the Production, C. onsumption and Price Models of the Natural Rubber Industry in Selected ASEAN Countries and World Market. Asian Journal of Economic Modelling, 6(4), 403-418.

Fornell, C., \& Larcker, D. F. (1981). Evaluating structural equation models with unobservable variables and measurement error. Journal of marketing research, 39-50.

Hair, J., Hollingsworth, C. L., Randolph, A. B., \& Chong, A. Y. L. (2017). An updated and expanded assessment of PLSSEM in information systems research. Industrial Management \& Data Systems, 117(3), 442-458.

Hair, J. F. (2010). Black, WC, Babin, BJ, \& Anderson, RE (2010). Multivariate data analysis, 7.

Hair, J. F., Ringle, C. M., \& Sarstedt, M. (2013). Partial least squares structural equation modeling: Rigorous applications, better results and higher acceptance.

Hair, J. F., Sarstedt, M., Pieper, T. M., \& Ringle, C. M. (2012). The use of partial least squares structural equation modeling in strategic management research: a review of past practices and recommendations for future applications. Long range planning, 45(5-6), 320-340.

Hameed, W. U., Basheer, M. F., Iqbal, J., Anwar, A., \& Ahmad, H. K. (2018). Determinants of Firm's open innovation performance and the role of R \& D department: an empirical evidence from Malaysian SME's. Journal of Global Entrepreneurship Research, 8(1), 29.

Haryanto, A. T., Dewi, S. N., \& Choerudin, A. (2020). The Effect of Development Research of Intensity and Competitive Management on Marketing Performance With Innovation Based Green Product as Mediator Variable: An Empirical Study. Journal of Talent Development and Excellence, 12(1), 4643-4654.

Henseler, J., \& Chin, W. W. (2010). A comparison of approaches for the analysis of interaction effects between latent variables using partial least squares path modeling. Structural Equation Modeling, 17(1), 82-109.

Henseler, J., Dijkstra, T. K., Sarstedt, M., Ringle, C. M., Diamantopoulos, A., Straub, D. W., . . Calantone, R. J. (2014). Common beliefs and reality about PLS: Comments on Rönkkö and Evermann (2013). Organizational Research Methods, 17(2), 182-209.

Henseler, J., Ringle, C. M., \& Sinkovics, R. R. (2009). The use of partial least squares path modeling in international marketing New challenges to international marketing (pp. 277-319): Emerald Group Publishing Limited.

Hofman, E., Schleimer, S. C., \& Faems, D. (2018). When does goodwill trust matter in interfirm new product development? Paper presented at the 25th Innovation and Product Development Management Conference 2018.

Iqbal, J., \& Kousar, S. (2018). Antecedents of Sustainable Social Entrepreneurship Initiatives in Pakistan and Outcomes: Collaboration between Quadruple Helix Sectors. Sustainability, 10(12), 4539.

Jermsittiparsert, K., Joemsittiprasert, W., Wasino, C. S., \& Budi, S. (2019). Quality Costing and Supplier Social Sustainability as Antecedents of Supply Chain Performance: A Case of Rubber Industry of Indonesia. Int. J Sup. Chain. Mgt Vol, 8(4), 492.

Nabayi, A., Teh, C., Husni, M., \& Sulaiman, Z. (2018). Plant Growth, Nutrient Content and Water Use of Rubber (Hevea brasiliensis) Seedlings Grown using Root Trainers and Different Irrigation Systems. Pertanika Journal of Tropical Agricultural Science, 41(1).

Navaratnarajah, S. K., \& Indraratna, B. (2018). Closure to "Use of Rubber Mats to Improve the Deformation and Degradation Behavior of Rail Ballast under Cyclic Loading” by Sinniah K. Navaratnarajah and Buddhima Indraratna. Journal of Geotechnical and Geoenvironmental Engineering, 144(7), 07018014.

Preacher, K. J., \& Hayes, A. F. (2008). Asymptotic and resampling strategies for assessing and comparing indirect effects in multiple mediator models. Behavior research methods, 40(3), 879-891.

Saffian, H. A., Harun, J., Tahir, P. M., \& Khalina, A. (2011). Feasibility of manufacturing a medium density fibreboard made of 4-year old rubber tree RRIM 2020 clone. Paper presented at the Key Engineering Materials. 
Schöggl, J.-P., Baumgartner, R. J., \& Hofer, D. (2017). Improving sustainability performance in early phases of product design: A checklist for sustainable product development tested in the automotive industry. Journal of Cleaner Production, $140,1602-1617$.

Shahab, Y., Ntim, C. G., Chen, Y., Ullah, F., Li, H. X., \& Ye, Z. (2020). Chief executive officer attributes, sustainable performance, environmental performance, and environmental reporting: New insights from upper echelons perspective. Business Strategy and the Environment.

Siuly, Li, Y., \& Wen, P. (2011). EEG signal classification based on simple random sampling technique with least square support vector machine. International journal of Biomedical Engineering and Technology, 7(4), 390-409.

Ul-Hameed, W., Mohammad, H., Shahar, H., Aljumah, A., \& Azizan, S. (2019). The effect of integration between audit and leadership on supply chain performance: Evidence from UK based supply chain companies. Uncertain Supply Chain Management, 7(2), 311-328.

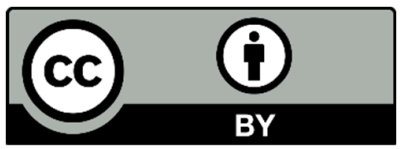

C 2021 by the authors; licensee Growing Science, Canada. This is an open access article distributed under the terms and conditions of the Creative Commons Attribution (CCBY) license (http://creativecommons.org/licenses/by/4.0/). 